\title{
A new Diplura species from Georgia caves, Plusiocampa (Plusiocampa) imereti (Diplura, Campodeidae), with morphological and molecular data
}

\author{
Alberto SENDRA ${ }^{1, *}$, Ferran PALERO ${ }^{2}$, Alba SÁNCHEZ-GARCÍA $^{3}$, \\ Alberto JIMÉNEZ-VALVERDE ${ }^{4}$, Jesús SELFA $^{5}$, Eter MAGHRADZE ${ }^{6} \&$ \\ Shalva BARJADZE ${ }^{7}$
}

${ }^{1}$ Colecciones Entomológicas Torres-Sala, Servei de Patrimoni Històric, Ajuntament de València, Passeig de la Petxina, 15, 46008 València, Spain.

${ }^{1}$ Departament de Didàctica de les Ciències Experimentals i Socials, Facultat de Magisteri,

Universitat de València, Avda. Tarongers 4, 46022 València, Spain.

${ }^{2}$ Institut Cavanilles de Biodiversitat i Biologia Evolutiva, Universitat de Valencia, C/ Catedrático José Beltrán 2, 46980 Paterna, Spain.

${ }^{2}$ Department of Life Sciences, The Natural History Museum, Cromwell Road, London SW7 5BD, UK.

${ }^{3}$ Departament de Botànica i Geologia, Facultat de Ciències Biològiques, Universitat de València,

C/ Dr. Moliner 50, 46100 Burjassot, València, Spain.

${ }^{3}$ Division of Invertebrate Zoology, American Museum of Natural History, Central Park West at $79^{\text {th }}$

Street, New York, NY 10024-5192, USA.

${ }^{4}$ Universidad de Alcalá, Research Team on Soil Biology and Subterranean Ecosystems, Department of Life Sciences, Faculty of Science, Campus Universitario Crta. A-2 Km. 33.6, E-28805, Alcalá de Henares, Madrid, Spain.

${ }^{5}$ Laboratori d'Investigació d'Entomologia, Departament de Zoologia, Universitat de València, C/ Dr. Moliner 50, 46100 Burjassot, València, Spain.

${ }^{6,7}$ Institute of Zoology, Ilia State University, Giorgi Tsereteli 3, 0162, Tbilisi, Georgia.

*Corresponding author: alberto.sendra@uv.es

2Email: Ferran.Palero@uv.es

3Email: alba.sanchez@uv.es

${ }^{4}$ Email: alberto.jimenezv@uah.es

${ }^{5}$ Email: jesus.selfa@uv.es

${ }^{6}$ Email: eter.magradze.1@iliauni.edu.ge

${ }^{7}$ Email: shalva.barjadze@yahoo.com

\footnotetext{
${ }^{1}$ urn:1sid:zoobank.org:author:11636BAE-AE66-4898-A7C8-35B329E7E3A8

${ }^{2}$ urn:lsid:zoobank.org:author:6FDDFE46-501A-4D6E-975E-72F55617775C

${ }^{3}$ urn:1sid:zoobank.org:author:86DFDA66-BEC1-428A-A7B0-E90FCFFABCE3

${ }^{4}$ urn:lsid:zoobank.org:author:E31ADC69-98EE-46CB-87E2-5B27B53FF107

${ }^{5}$ urn:lsid:zoobank.org:author:C01B4FA6-6C5C-4DDF-A114-2B06D8FE4D20

${ }^{6}$ urn:1sid:zoobank.org:author:A5CE76D6-214B-40D8-B06D-181C0AB4D7C9

${ }^{7}$ urn:lsid:zoobank.org:author:63ABE1B2-8A56-42C8-BC34-1119D3A2ECBC
} 


\begin{abstract}
A new dipluran species, Plusiocampa (Plusiocampa) imereti Sendra \& Barjadze sp. nov., from the deep zone in three caves in the Imereti region, Georgia, is described. This new troglobitic Plusiocampa is an addition to four others known Diplura from around the Black Sea region, two Dydimocampa and two Plusiocampa s. str. The present study also provides the first CO1 sequences for the Plusiocampinae taxa and the first molecular data for cave-dwelling Plusiocampa species. Although bootstrap values were low, the maximum-likelihood phylogenetic tree grouped Plusiocampa (P.) imereti Sendra \& Barjadze sp. nov. with two Plusiocampa s. str. species from Eastern Europe. Morphologically, $P$. (P.) imereti Sendra \& Barjadze sp. nov. is closely related to two cave-dwelling species: Plusiocampa (Plusiocampa) glabra Condé, 1984 and Plusiocampa (P.) chiosensis Sendra \& Gasparo, 2020. The new species can be distinguished by the presence of lateral anterior macrosetae on metanotum, more uneven claws, and the presence of $2+2$ lateral anterior macrosetae on middle urotergites. The five species currently known for the Black Sea region inhabit caves located at low altitude but with no influence from former glacial or permafrost processes.
\end{abstract}

Keywords. Plusiocampinae taxonomy, phylogeny, cave-dwelling, biogeography.

Sendra A., Palero F., Sánchez-García A., Jiménez-Valverde A., Selfa J., Maghradze E. \& Barjadze S. 2021. A new DipluraspeciesfromGeorgiacaves, Plusiocampa(Plusiocampa)imereti(Diplura,Campodeidae), withmorphological and molecular data. European Journal of Taxonomy 778: 71-85. https://doi.org/10.5852/ejt.2021.778.1567

\title{
Introduction
}

Plusiocampa Silvestri, 1912 is a relatively well-known genus of the subfamily Plusiocampinae, part of the most diverse family of Diplura (i.e., Campodeidae Lubbock, 1873; Sendra et al. 2021a). Seventyfive Plusiocampa species have been described so far, mostly cave-dwellers distributed throughout the Mediterranean and Black Sea regions but some inhabiting soil ecosystems (Sendra et al. 2021a, 2021b) (Fig. 1). Four species of Plusiocampa are already known from caves around the Black Sea, at the western side in the well-known Movile Cave in Dobroudja (Condé 1993, 1996); caves from the Crimean Peninsula in the north (Silvestri 1949; Sendra et al. 2020a), and a cave near the Abkhazia coast in the east (Sendra et al. 2020a). Recently collected specimens of Plusiocampa, found in three caves in the Imereti Plateau (Georgia), have allowed us to describe one more species using morphological and, for the first time, molecular data.

Campodeoidea DNA sequences are poorly represented in current databases (only $14.6 \%$ of the dipluran sequences; NCBI accession date 29/04/2021), and data are highly skewed towards a handful of taxa. Only 15 Campodeoidea identified to species level are represented in Genbank, and only 5 of those include a DNA barcode (Remycampa herbanica Sendra \& Oromí, 2020, Campodea fragilis Meinert, 1865, C. lubbocki Silvestri, 1912, C. tillyardi Silvestri, 1931 and Lepidocampa weberi Oudemans, 1890). Previous studies have focused on sequence variation in nuclear ribosomal genes (18S rDNA and $28 \mathrm{~S}$ rDNA), but these genes provide little resolution for evolutionary relationships within Campodeidae (Luan et al. 2005; Sendra et al. 2020b). The present study contributes the first CO1 sequences for Plusiocampinae taxa and the first molecular data for cave-dwelling species of Plusiocampa.

\section{Material and methods}

Diplurans were sampled by hand using an aspirator in the dark zones of the Datvis (Bear), Melouri, and Shvilobisa caves in 2018 and 2019. Specimens were transferred to vials containing 70\% ethanol. 


\section{Morphological study}

In the laboratory, specimens were washed with distilled water, mounted on a slide with Marc André II solution, and examined under a phase-contrast optical microscope (Leica DMLS). Illustrations were made with a drawing tube and measurements were taken with an ocular micrometre. To determine body length, specimens were mounted in toto and measured from the base of the distal macrochaetae on the frontal process to the supra-anal abdominal valve. Four specimens were coated with palladium-gold for SEM photography (Hitachi S-4900) and sensilla measurements. The morphological descriptions and abbreviations follow Condé (1956). The term 'gouge sensilla' is used for the concavo-convex shaped sensilla on the antennae, following Bareth \& Condé (1981).

\section{Abbreviations for morphological measurements}

For the position of macrosetae, we adopted the abbreviations of Condé (1955).
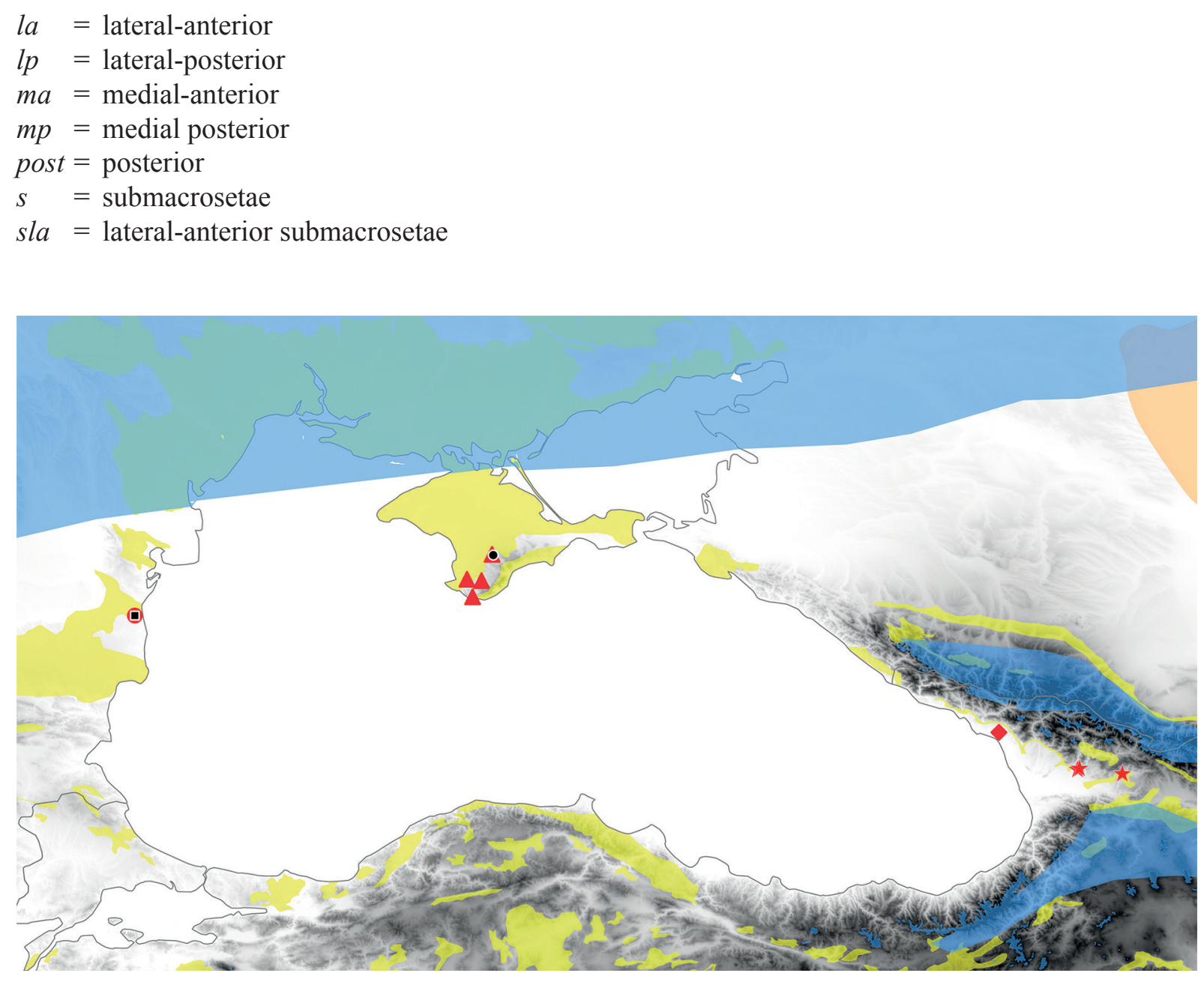

Fig. 1. Distribution map of cave-adapted diplurans in the Black Sea region: Plusiocampa (Plusiocampa) isterina Condé, 1993 (red circle), Plusiocampa (Dydimocampa) evallonychia Silvestri, 1949 (red triangles), Plusiocampa (Plusiocampa) imereti Sendra \& Barjadze sp. nov. (red stars), Plusiocampa (Plusiocampa) aff. dublanskii Sendra \& Turbanov, 2020 (red rhombus), Plusiocampa (Dydimocampa) euxina Condé, 1996 (black square), Plusiocampa (Plusiocampa) dublanskii Sendra \& Turbanov, 2020 (black circle). Yellow $=$ karst areas (source: Chen et al. 2017); orange $=$ deserts (source: Olson \& Dinerstein 2002); blue = ice cover and permafrost extent during the Last Glacial Maximum (sources: Ehlers et al. 2011; Lindgren et al. 2016). 


\section{Institutional abbreviations}

Coll AS $\quad=$ private collection of Alberto Sendra, València, Spain

IZISU $\quad=$ Institute of Zoology at Ilia State University, Georgia

MZB $(\mathrm{MCNB})=$ Museu de Ciències Naturals de Barcelona, Spain

\section{Molecular analysis}

Total genomic DNA was isolated from ethanol-preserved tissues using commercial extraction kits (NucleoSpin kit, Macherey-Nagel ${ }^{\mathrm{TM}}$ ). Therefore, we decided to amplify the most variable CO1 gene fragment with the universal primers LCO1490 and HCO2198 (Folmer 1994), commonly used for DNA barcoding. The thermal profile of the polymerase chain reaction (PCR) used was $94^{\circ} \mathrm{C}$ for $15 \mathrm{~min}$ for polymerase activation (HotStart), followed by 38 cycles of $94^{\circ} \mathrm{C}$ for $30 \mathrm{~s}, 50^{\circ} \mathrm{C}$ for $30 \mathrm{~s}, 72^{\circ} \mathrm{C}$ for $30 \mathrm{~s}$, and a final extension at $72^{\circ} \mathrm{C}$ for $20 \mathrm{~min}$. Amplified PCR products were cleaned with Exo-SAP enzyme prior to direct product sequencing in an ABI Prism 3770 (Macrogen, Spain).

Chromatograms were checked using BioEdit ver. 7.2.5 (Hall 1999), and all sequences were translated into amino acids to detect possible insertions and/or stop codons to rule out the presence of pseudogenes, and a sequence alignment was performed using the MAFFT program with default parameters. To improve reliability, conserved (ungapped) blocks of sequence were extracted from each alignment using the Gblocks server under default settings (Castresana 2000). The CO1 gene has been suggested as an informative molecular marker at several taxonomic scales, particularly at the species level. Therefore, K2P genetic distances were obtained for the CO1 dataset using MEGA ver. 7 (Kumar et al. 2016) to compare with estimates in other taxa. The best-fitting substitution model was tested using MrAIC ver. 1.4.6 (Nylander 2004) and selected with a correction for small sample sizes according to the Akaike information criterion (AICc). The maximum-likelihood (ML) phylogenetic tree construction method was applied as implemented in Phyml ver. 3.0 (Guindon et al. 2010).

\section{Results}

Class Diplura Börner, 1904

Superfamily Campodeoidea Lubbock, 1873

Family Campodeidae Lubbock, 1873

Subfamily Plusiocampinae Plact, 1957

Genus Plusiocampa Silvestri, 1912

Plusiocampa (Plusiocampa) imereti Sendra \& Barjadze sp. nov. urn:1sid:zoobank.org:act:40C3DB96-19CD-4354-ACA9-434F0ADA34BB

Figs 2-12

\section{Diagnosis}

Troglomorphic species. Antennae with 39-45 antennomeres; 12 complex olfactory chemoreceptors within cupuliform organ; non-protruding frontal process slightly protruding, plain, with non-tubercular setae or just slightly tubercular. Pronotum $1+1 m a, 2+2 l a_{1,2}, 2+2 l p_{2,3} ;$ mesonotum with $1+1 m a, 3+3$ $l a_{1-3}, 2+2 l p_{2,3}, 1+1 \mathrm{mp}$; metanotum with $1+1 \mathrm{ma}, 2+2 l a_{1,2}$ or $s l a_{1,2}, 1+1 l p_{2}, 1+1 \mathrm{mp}$; thin; all notal macrosetae long and covered by thin barbs on half to distal portions; thin, middle-sized clothing setae covered by $0-4$ thin distal barbs. Legs elongated, pretarsus of metathoracic legs slightly overpasses end of abdomen. Femora I-III with one long, barbed dorsal macroseta and one shorter, barbed ventral macroseta. Tibiae I-III with two short barbed ventral macrosetae. Claws unequal (posterior claw $1.3 \times$ as long as anterior one); large, backward overhang on posterior claw; lateral crests well-developed. Pretarsal process long and setiform. Urotergites $1+1$ post $_{1}$ on I-II; $0+0,0+1$ or $1+1$ la, $1+1$ or $2+2$ post $t_{l, 2}$ on III; $1+1 l_{3}, 2+2$ to $4+4$ post $_{l-4}$ on IV; $2+2$ la $_{2,3}, 4+4$ post $_{l-4}$ on V-VII; $6+6$ post $_{l-6}$ on VIII and $8+8$ 
or $8+7$ post $_{1-8}$ on abdominal IX. Urosternite I with 8+8-7+7 macrosetae (Figs 8-9); urosternites II-VII with $6+6$ macrosetae; urosternite VIII with $2+2$ macrosetae. Male urosternite I (Fig. 8) with slightly enlarged subcylindrical appendages, each bearing up to 21 glandular $a_{l}$ setae. Female appendages slightly thinner, with up to 11 glandular $a_{l}$ setae.

\section{Etymology}

The specific epithet refers to the Imereti region, the location of the Shvilobisa Cave, treated as a noun in apposition.

\section{Type material}

\section{Holotype}

GEORGIA • + , "holotype- + IZISU-TD-T-00001"; Shvilobisa Cave, Bunikauri village, Chiatura

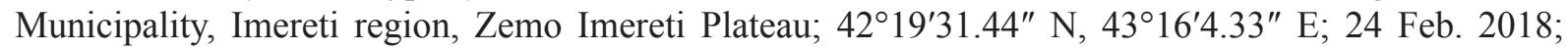
Shalva Barjadze and Eter Maghradze leg.; IZISU-TD-T-00001.

\section{Paratypes}

GEORGIA • 1 ภ, "paratype- ${ }^{\Uparrow} 1$ IZISU-TD-T-00002"; same collection data as for holotype; IZISUTD-T-00002 • 1 क , "paratype- 1 MZB (MCNB) 2021-2336"; same locality as for holotype; $20 \mathrm{Jul}$. 2020; Eter Maghradze leg.; MZB (MCNB) 2021-2336 • 1 ㅇ, "paratype- 2 MZB (MCNB) 2021-2337”;

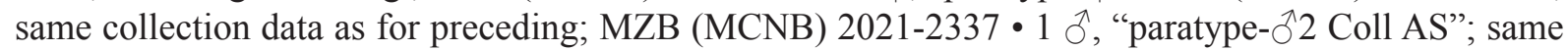
collection data as for preceding; Coll AS.

\section{Other material}

GEORGIA - 2 specs, unknown sex [for SEM photography and one specimen for DNA analysis]; Shvilobisa Cave; 24 Feb. 2018; Shalva Barjadze and Eter Maghradze leg. 2 specs [for SEM photography and one for DNA analysis]; same collection data as for preceding; 20 Jul. 2020; Eter Maghradze leg.

\section{Other material from two other caves (all Coll AS)}

GEORGIA • 1 \%; Kumistavi village Tskaltubo Municipality, Imereti Region, Sataplia-Tskaltubo karst

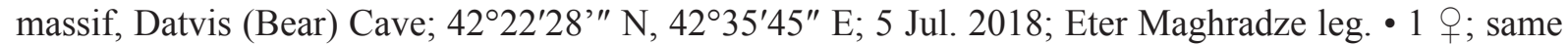
collection data as for preceding; 1 Sept. 2019 - 1 त; near Melouri village, Tskaltubo Municipality, Imereti Region, Sataplia-Tskaltubo karst massif, Melouri Cave; 42²3'15.1" N, 42³7'41.5" E; 1 Nov. 2018; Eter Maghradze leg.

\section{Description}

Body. Body length 4.3-7.2 mm (females) and 4.9-5.2 mm (males) (Table 1). Epicuticle smooth under optical microscope and SEM; body with thin, middle-sized clothing setae covered by $0-4$ thin distal barbs.

HeAD. Three intact antennae, all slightly longer than body length, with 39-45 antennomeres (Table 1). Small, thin, subcylindrical sensillum on third antennomere located in ventral position between $\mathrm{c}$ and $\mathrm{d}$ macrosetae. Central antennomeres $2.1 \times$ as long as wide, apical antennomere $3.0 \times$ as long as wide. Cupuliform organ occupying $1 / 3$ of total length of apical antennomere, with about 12 complex olfactory chemoreceptors. Each olfactory chemoreceptor is composed of a complete fold surrounding a central cylinder with two lateral expansions, entirely reticulated and perforated (Fig. 5). Gouge sensilla 30$40 \mu \mathrm{m}$ long, in a single distal whorl of 13-16 sensilla on each medial and distal antennomere. Frontal process slightly protruding, plain, with non-tubercular setae or just slightly tubercular on distal portion (Fig. 3); macrosetae along the insertion line of antennomere and $i$ macrosetae and $x$ setae longer than other macrosetae $(a / i / p / x$ with relative lengths of $25 / 36 / 19 / 37$ in holotype). Suboval labial palps with 

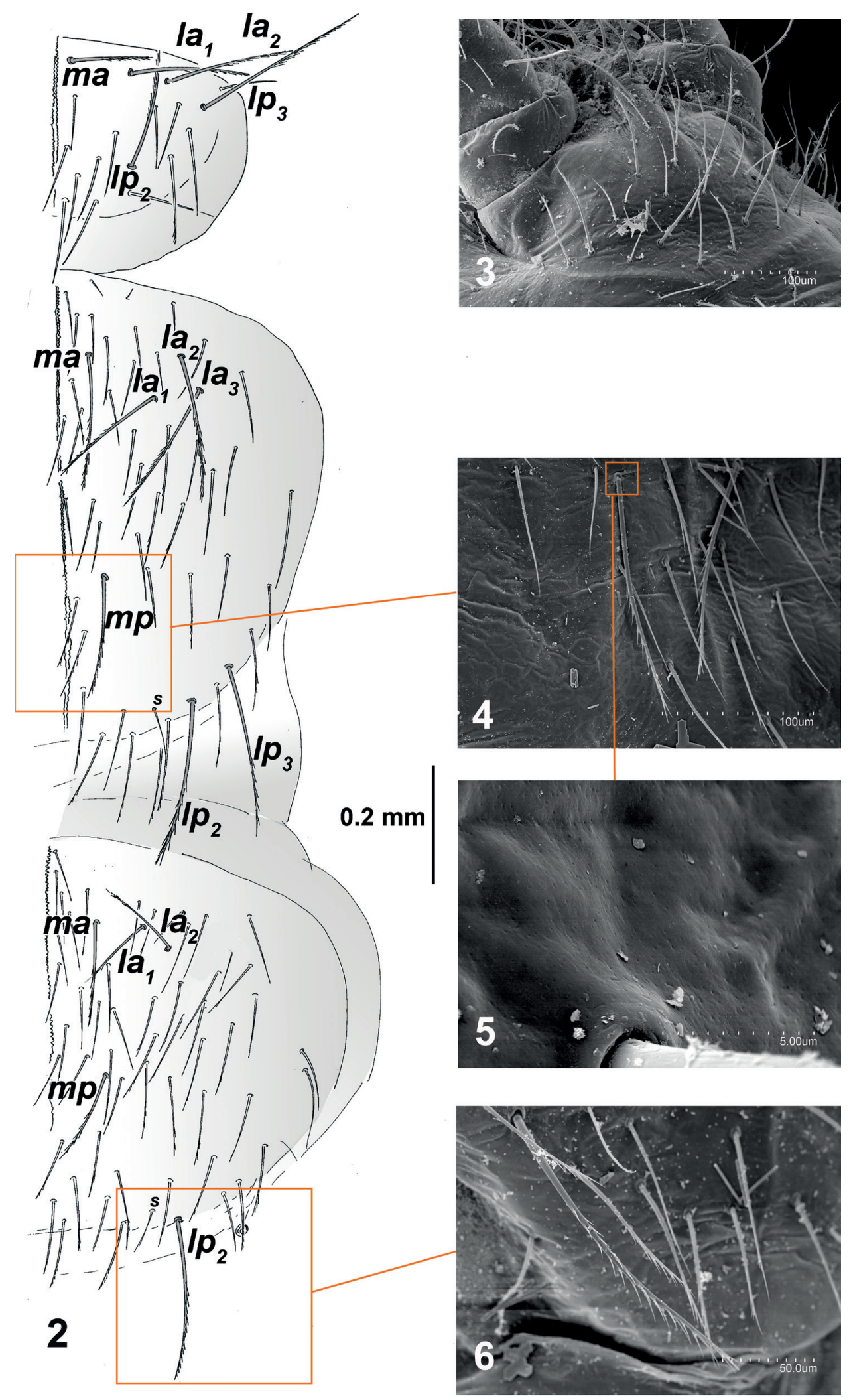

Figs 2-6. Plusiocampa (Plusiocampa) imereti Sendra \& Barjadze sp. nov., +, holotype (IZISUTD-T-00001). 2. Thoracic nota. 3. Frontal process. 4. Detail of mesonotum. 5. Detail of mesonotum at high magnification. 6. Detail of metanotum. 


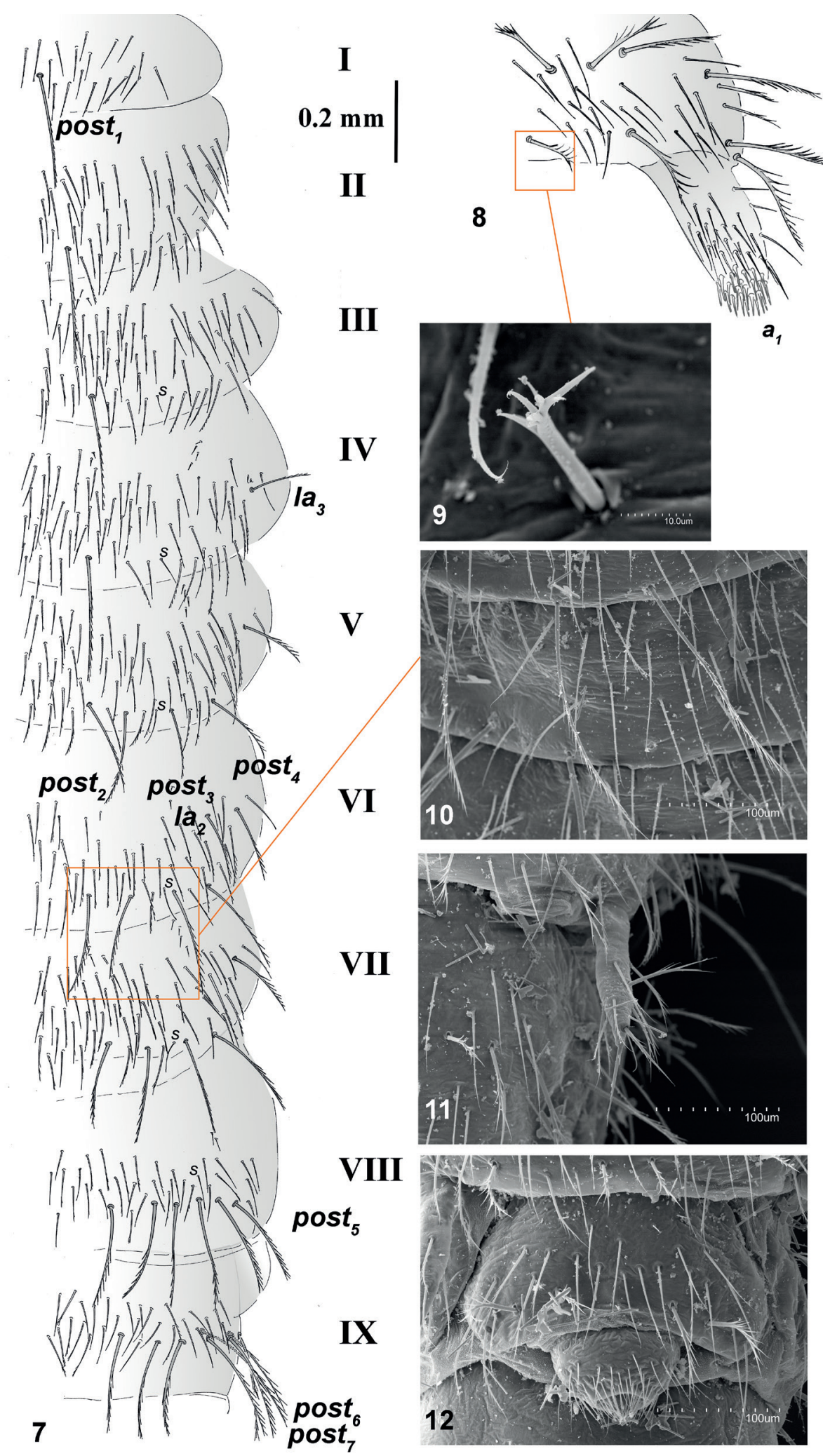

Figs 7-12. Plusiocampa (Plusiocampa) imereti Sendra \& Barjadze sp. nov., 9 , holotype (IZISUTD-T-00001). 7. Urotergites I-IX. 8. First urosternite of the male, lateral side. 9. Macrosetae of first urosternite of the male. 10. Detail of sixth urotergite. 11. Detail of six urosternite. 12. Eight urosternite of male. $a_{1}=$ glandular setae on distal portion of appendages. 
Table 1. Measurements for Plusiocampa (Plusiocampa) imereti Sendra \& Barjadze sp. nov. Body length, antennae and metathoracic leg articles (in $\mathrm{mm}$ ), and number of antennomeres.

\begin{tabular}{|c|c|c|c|c|c|c|c|c|}
\hline \multirow{2}{*}{ Specimens } & \multirow{2}{*}{$\begin{array}{l}\text { Body } \\
\text { length }\end{array}$} & \multicolumn{2}{|c|}{ Antennae } & \multicolumn{5}{|c|}{ Metathoracic legs } \\
\hline & & Length & Antennomeres & Coxa & Trochanter & Femur & Tibia & Tarsus \& pretarsus \\
\hline $\begin{array}{c}\text { holotype } q \\
\text { IZISU-TD-T-00001 }\end{array}$ & 7.2 & - & - & 0.4 & 0.4 & 1.1 & 1.3 & 0.9 \\
\hline $\begin{array}{c}\text { paratype- } 91 \mathrm{MZB} \\
\text { (MCNB) } \\
2021-2336\end{array}$ & 6.0 & 6.5 & 44 & 0.3 & 0.3 & 0.9 & 1.0 & 0.8 \\
\hline $\begin{array}{c}\text { paratype- }{ }^{\lambda} 1 \\
\text { IZISU-TD-T00002 }\end{array}$ & 5.2 & 6.5 & 39 & 0.2 & 0.2 & 0.9 & 1.0 & 0.8 \\
\hline 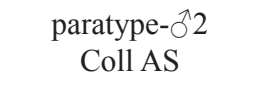 & 4.9 & 6.0 & 45 & 0.2 & 0.2 & 0.8 & 0.9 & 0.7 \\
\hline $\begin{array}{c}\text { paratype- } \$ 2 \text { MZB } \\
\text { (MNCB) } \\
2021-2337\end{array}$ & 4.3 & - & - & 0.2 & 0.2 & 0.8 & 0.9 & 0.7 \\
\hline
\end{tabular}

Table 2. Measurements for Plusiocampa (Plusiocampa) imereti Sendra \& Barjadze sp. nov. Body length, cerci, and cercal articles (in $\mathrm{mm}$ ). $*=$ probably regenerated.

\begin{tabular}{|c|c|c|c|c|c|c|c|c|c|c|c|}
\hline \multirow{3}{*}{ Specimens } & \multirow{3}{*}{$\begin{array}{l}\text { Body } \\
\text { length }\end{array}$} & \multicolumn{10}{|c|}{ Cerci } \\
\hline & & \multirow{2}{*}{$\begin{array}{c}\text { Base (number } \\
\text { of secondary ar- } \\
\text { ticles) }\end{array}$} & \multicolumn{8}{|c|}{ Primary articles } & \multirow{2}{*}{$\begin{array}{l}\text { Total } \\
\text { length }\end{array}$} \\
\hline & & & $1^{\text {st }}$ & $2^{\text {nd }}$ & $3^{\text {rd }}$ & $4^{\text {th }}$ & $5^{\text {th }}$ & $6^{\text {th }}$ & $7^{\text {th }}$ & $8^{\text {th }}$ & \\
\hline $\begin{array}{c}\text { paratype-p1 } \\
\text { MZB (MCNB) } \\
2021-2336\end{array}$ & 6.0 & $1.4(3)$ & 0.8 & 0.9 & 1.0 & 1.1 & 1.5 & 1.5 & - & - & 8.2 \\
\hline $\begin{array}{c}\text { paratype- }{ }^{\wedge} 2 \\
\text { Coll AS }\end{array}$ & 4.9 & $2.1(4)$ & 0.9 & 1.2 & 1.3 & 1.7 & 1.8 & - & - & - & $9.0^{*}$ \\
\hline $\begin{array}{c}\text { paratype- } 92 \\
\text { MZB (MCNB) } \\
2021-2337\end{array}$ & 4.3 & $2.0(7)$ & 0.5 & 0.5 & 0.6 & 0.8 & 0.8 & 0.9 & 0.9 & 1.0 & $8.0^{*}$ \\
\hline
\end{tabular}

a bacilliform latero-external sensillum, two guard setae, up to 7 setae on anterior border, and up to 130 neuroglandular setae in holotype.

Thorax. Thoracic macrosetal distribution (Figs 2, 4, 6): pronotum with $1+1 m a, 2+2 l a_{l-2}, 2+2 l p$; mesonotum with $1+1 \mathrm{ma}, 3+3 l a_{l-3}, 2+2 l p_{2,3}, 1+1 \mathrm{mp}$; metanotum with $1+1 \mathrm{ma}, 2+2 l a_{1,2}$ or $s l a_{1,2}$, $1+1 l p, 1+1 \mathrm{mp}$. All notal macrosetae are long and covered by thin barbs on half to distal portions (Figs 4, 6); submacrosetae sla are thinner and shorter than notal macrosetae; marginal setae are similar to clothing setae, and covered by 1-8 thin distal barbs. Legs elongated, pretarsus of metathoracic legs slightly overpasses end of abdomen (Table 1). Femora I-III with one long, barbed dorsal macroseta and one shorter, barbed ventral macroseta. Tibiae I-III with two short barbed ventral macrosetae. Calcars with 4-5 long barbs. Tarsi with two rows of thicker ventral setae with 2-3 very thin barbs on middle portion. Two dorsal and one ventral, smooth, subapical tarsal setae. Claws are unequal (posterior claw $1.3 \times$ as long as anterior one); large, backward overhang on posterior claw; lateral crests well-developed. Pretarsal process long and setiform, overpassing end of claws.

AвDomen. Distribution of abdominal macrosetae on tergites (Fig. 7): $1+1$ post $t_{1}$ on I-II; $0+0,0+1$ or $1+1$ la $1+1$ or $2+2$ post $_{l, 2}$ on III; $1+1 l_{3}, 2+2$ to $4+4$ post $_{l-4}$ on IV; $2+2 l a_{2,3}, 4+4$ post $_{1-4}$ on V-VII; 
$6+6$ post $_{1-6}$ on VIII and $8+8$ or $8+7$ post $_{1-8}$ on abdominal segment IX. All post urotergal macrosetae long and covered by thin barbs along distal four-fifths (Fig. 10); la urotergal macrosetae shorter than post macrosetae, covered by barbs along distal half. Urosternite I with 8+8-7+7 macrosetae (Figs 8-9); urosternites II-VII with 6+6 macrosetae; urosternite VIII with 2+2 macrosetae (Fig. 12); all urosternal macrosetae robust and large, covered by long barbs along distal third to four-fifths. Apical, subapical and ventromedial setae with a few (two to four) thin, short and long barbs (Fig. 11).

SECONDARY SEX CHARACTERS. Male urosternite I (Fig. 8) with slightly enlarged subcylindrical appendages, each bearing up to 21 glandular $a_{1}$ setae. Female appendages slightly thinner, with up to 11 glandular $a_{l}$ setae. Spermatozoid fascicles $40 \mu \mathrm{m}$ in diameter without apparently spiral filament.

\section{Molecular analysis}

The nucleotide substitution model selected was $G T R+G+I(B I C=6998.6)$, with the proportion of invariant sites $(I=0.46)$ and estimated alpha parameter for the gamma distribution $(\alpha=1.39)$, indicating a significant heterogeneity in the DNA substitution among sites. The Campodeidae sequences formed a well-supported clade, clearly distinct from that of Japygidae (Fig. 13). Although bootstrap values were low, the ML phylogenetic tree grouped Plusiocampa (P.) imereti Sendra \& Barjadze sp. nov. with Eastern Europe taxa such as Plusiocampa (Plusiocampa) aff. elongata Ionescu, 1955 and Plusiocampa (Plusiocampa) humicola Ionescu, 1955, whereas Iberian Peninsula taxa (Plusiocampa (Plusiocampa) gadorensis Sendra, 2001, Plusiocampa (Plusiocampa) baetica Sendra, 2004 and Cestocampa iberica Sendra \& Condé, 2012) clustered in a distinct clade. K2P genetic distances also showed $P$. (P.) aff. elongata $(0.206 \pm 0.027)$ and $P$. $(P$.) humicola $(0.205 \pm 0.028)$ to be the closest species to the new Plusiocampa (P.) imereti Sendra \& Barjadze sp. nov. from Georgia.

\section{Habitat}

Plusiocampa (Plusiocampa) imereti Sendra \& Barjadze sp. nov. inhabits the deep zone (over $50 \mathrm{~m}$ from the entrance) of three caves. The Shvilobisa Cave, the type locality, is a $1000 \mathrm{~m}$ long, tunnellike, easily accessible sub-horizontal cave with a small subterranean water stream (Tatashidze et al. 2009b). The others two nearby caves are about $55 \mathrm{~km}$ away from the Shvilobisa Cave; the Melouri Cave is 5300 meters long and has the status of natural monument (Tatashidze et al. 2009b), whereas the Datvis Cave is a poorly known cavern (K. Tsikarishvili, pers. comm.). The distance between the Datvis and Melouri caves is ca $3.5 \mathrm{~km}$. The Melouri Cave - easily accessible - has dried halls and a permanent subterranean water stream near its end. This cave has gigantic stalagmites and fallen stones. The Datvis Cave is a horizontal, dry, and easily accessible cave with several halls, which are rich in different speleothems like the Shvilobisa Cave (Tatashidze et al. 2009b).

\section{Invertebrate cavernicolous species of the studied caves}

The three caves (Shvilobisa, Datvis, and Melouri) which Plusiocampa (Plusiocampa) imereti Sendra \& Barjadze sp. nov. inhabits are also the dwellings of other troglobitic arthropod species. Datvis and Melouri caves share three troglobitic species: the Diplopoda Leucogeorgia prometheus Antić \& Reip, 2020, the Isopoda Colchidoniscus kutaissianus Borutzky, 1974, and the Pseudoscorpionida Chthonius satapliaensis Schawaller \& Dashdamirov, 1988. In addition, the Insecta (Carabidae Coleoptera) Troglocimmerites imereti Dolzhanski \& Ljovuschkin, 1985 dwells in the Datvis cave; and the Melouri Cave has five more species: the Opiliones Nemaspela melouri Martens, Maghradze \& Barjadze, 2021, the Araneae Centromerus bulgarianus Drensky, 1931, the Hexapoda Collembola Pseudacherontides zenkevitchi Djanashvili, 1971; the Insecta (Carabidae Coleoptera) Inotrechus kurnakovi Dolzhanski \& Ljovuschkin, 1989; and Troglocimmerites sp. 1. In the Shvilobisa Cave, eight troglobitic species dwell: the Diplopoda Leucogeorgia gioi Antić \& Reip, 2020, the Isopoda Caucasonethes cf. borutzkyi Verhoeff, 1932 and Colchidoniscus sp., the Pseudoscorpionida Chthonius satapliaensis Schawaller \& 


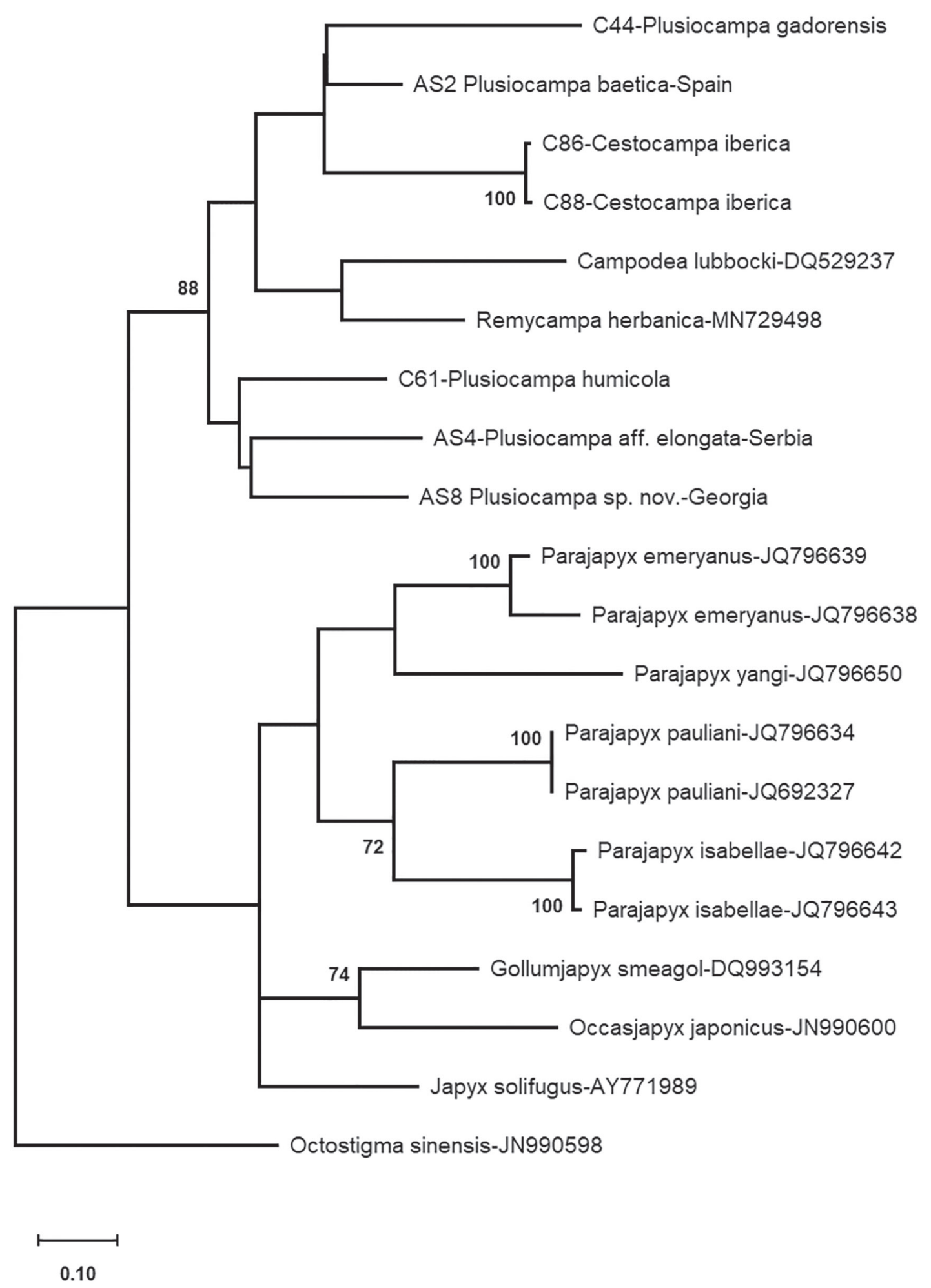

Fig. 13. Maximum likelihood (ML) tree of Diplura obtained from CO1 data. Only bootstrap support values above 70 are shown. 
Dashdamirov, 1988, the Opiliones Nemaspela sp., the Hexapoda Collembola Oncopodura sp. and Pseudosinella sp., and the Insecta (Carabidae Coleoptera) Troglocimmerites sp. 2. (Barjadze et al. 2019; Maghradze et al. 2019; Antić \& Reip 2020; Martens et al. 2021; Maghradze \& Barjadze, unpublished data).

\section{Discussion}

\section{Phyletic affinities}

The notal macrosetae pattern of Plusiocampa (Plusiocampa) imereti Sendra \& Barjadze sp. nov., with medial posterior macrosetae, in addition to $1+1$ lateral posterior macrosetae on the metanotum, shows similarities with three species of Plusiocampa s. str. These are the cave-dwelling species Plusiocampa (Plusiocampa) glabra Condé, 1984 from a cave in Corinthos in the southern Balkan Peninsula; Plusiocampa (Plusiocampa) chiosensis Sendra \& Gasparo, 2020 from Chios Island, west of the Anatolian Peninsula; and Plusiocampa (Plusiocampa) hoelzeli (Neuherz, 1984) from caves in the alpine karst between Austria and Slovenia. The extremely unequal claws (1.5) and absence of medial and lateral anterior macrosetae on the metanotum distinguish $P$. (P.) hoelzeli from $P$. (P.) imereti Sendra \& Barjadze sp. nov. (Neuherz 1984; Sendra et al. 2020a), which has claws that are less unequal (1.3) and medial and lateral anterior macrosetae on the metanotum. Several taxonomical differences also separate $P$. (P.) chiosensis and P. glabra from P. (P.) imereti Sendra \& Barjadze sp. nov. Plusiocampa (P.) chiosensis and $P$. glabra have no lateral anterior macrosetae on the metanotum, subequal or slightly unequal claws (1-1.1), and 1+1 lateral anterior macrosetae on middle urotergites, whereas $P$. (P.) imereti Sendra \& Barjadze sp. nov. has lateral anterior macrosetae on the metanotum, more unequal claws, and $2+2$ lateral anterior macrosetae on middle urotergites.

These phyletic relationships based on morphological evidence have been supported for the first time in Campodeidae by molecular evidence. Thus, the molecular results confirm Plusiocampinae to be a monophyletic group, as previously proposed in Condé (1956), Paclt (1957), and Sendra et al. (2020a). Furthermore, the CO1 tree suggests that Plusiocampa s. str., with medial posterior macrosetae on the mesonotum and metanotum, is probably monophyletic, including $P$. (P.) humicola, $P$. (P.) aff. elongata Ionescu, 1955 and $P$. (P.) imereti Sendra \& Barjadze sp. nov. These phyletic affinities confirm those pointed out in several contributions (Condé 1956; Sendra et al. 2019, 2020a) based on morphological features and suggest that further analyses using both nuclear and mitochondrial genes should be completed in order to clarify the evolutionary relationships within Plusiocampinae.

\section{Biogeographical notes}

Plusiocampa is the most diverse genus of Plusiocampinae, with 74 species including the new one, spread around the Euro-Mediterranean Basin and the Black Sea. Furthermore, Plusiocampa and Plusiocampinae are also totally absent north of $50^{\circ} \mathrm{N}$ latitude, which roughly marks the southern limit of the ice during the Last Glacial Maximum from Belgium to Crimea (Sendra et al. 2020a; Sendra et al. 2021b). Most species of Plusiocampinae inhabit cave ecosystems, with only nine dwelling in moist, soil habitats.

Around the Black Sea region, five Plusiocampa species are known from caves in karst areas. Two of the species belong to the controversial and probably paraphyletic subgenus Dydimocampa Paclt, 1957 . The first one is Plusiocampa (Dydimocampa) evallonychia Silvestri, 1949, which was found in four caves from three karst massifs of the Crimean Peninsula (Mamut-Tshokrak Cave in Baidarsko-Balaklavsky massif, Kuban Cave and Nassonova [= Anlysha] Cave in Ai-Petrik massif, and Kizil Koba [= Krasnaya = I-El Koba] Cave Dolgorukovskiy). The second species is Plusiocampa (Dydimocampa) euxina Condé, 1996 which was found in the Pestera de la Movile cave, a hypogenic cave near Dobroudja on the western Black Sea coast (Condé 1996; Silvestri 1949; Sendra et al. 2020a). These Dydimocampa species co- 
occur with two other species of Plusiocampa s. str.: Plusiocampa (Plusiocampa) isterina Condé, 1993 in Movile Cave (Rumania) and Plusiocampa (Plusiocampa) dublanskii Sendra \& Turbanov, 2020 in the Kizil-Koba (= Krasnaya) Cave. A probably new taxon, apparently related to $P$. (P.) dublanskii, $P$. (P.) aff. dublanskii, has been found in the Abrskila Cave, Abkhazia, near the eastern Black Sea coast (Condé 1993; Sendra et al. 2020a). Finally, P. (P.) imereti Sendra \& Barjadze sp. nov. is described from three caves located in the Imereti region in two neighboring areas (Zemo Imereti Plateau: Shvilobisa Cave; Sataplia-Tskaltubo karst massif: Datvis (Bear) Cave and Melouri Cave) (Figs 14-18).

All the localities of species of Plusiocampa in the Black Sea region are found in karst caves located at low altitudes, not far away from the coastline (Fig. 1). None of them exceed the ice-covered areas (glacier or permafrost) during the Last Glacial Maximum (Fig. 1). Furthermore, no troglobitic campodeids are
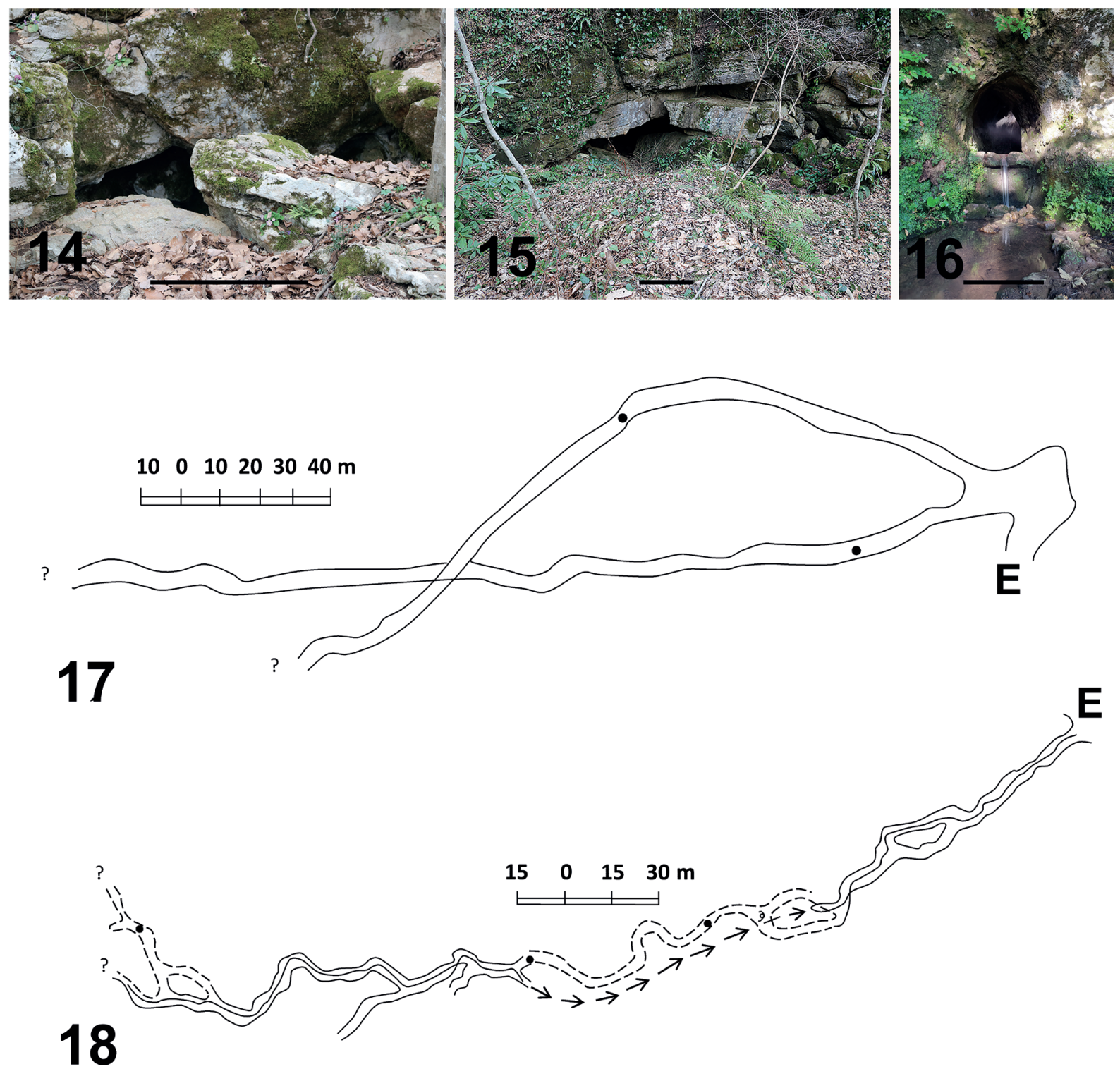

Figs 14-18. 14-16. Entrances. 17-18. Plans of the studied caves. 14. Datvis Cave. 15. Melouri Cave. 16. Shvilobisa Cave. 17. Plan of the Melouri Cave (Tatashidze et al. 2009a). 18. Plan of the Shvilobisa Cave (Tatashidze et al. 2009a). Black dots $=$ locations where the specimens of the new species were sampled; $\mathrm{E}=$ entrance.Scale bares: $14-16=1 \mathrm{~m}$. 
known for the Black Sea in high altitude caves, such as the Arabika Massif in West Caucasus where several biospeleological campaigns have been launched into the deepest caves of the world (Turvanov et al. 2018; Sendra \& Reboleria 2012). The southern area of the Black Sea lacks records of any caveadapted species of Plusiocampa or troglobitic diplurans in spite of occasional biospeleological visits, which also occurs in the caves of other regions such as the Pontic Mountains (Sendra et al. 2006, 2010).

\section{Acknowledgments}

The authors thank the SEM facility of the Universitat de València led by a great team of professionals, as well as Lucia Maltez for the English revision of the text. FP acknowledges the projects "CIDEGENT/2019/028 - BIOdiversity PAtterns of Crustacea from Karstic Systems (BIOPACKS): molecular, morphological, and functional adaptations" funded by the Conselleria d'Innovació, Universitats, Ciència i Societat Digital and "PRO2021-S02-PALERO - Fauna aquàtica en coves anquihalines del País Valencià: un món encara per descriure" funded by the Institut d'Estudis Catalans. ASG is funded by an APOSTD2019 Research Fellowship from the Generalitat Valenciana and the European Social Fund (ESF). Sampling of the cave dwelling invertebrates was carried out within the frameworks of the Institutional Grant of Ilia State University, Tbilisi, Georgia: "Taxonomy, fauna and ecology of the invertebrates in the long and biospeleologically poorly investigated caves of Imereti and Samegrelo regions" and the grant "Conservation actions and invertebrate investigations in Sataplia-Tskaltubo karst caves, Georgia" supported by the Conservation Leadership Programme (CLP). We are grateful to the authors of the World Karst Aquifer Mapping project for providing the GIS data used in the map.

\section{References}

Antić D.Ž \& Reip H.R. 2020. The millipede genus Leucogeorgia Verhoeff, 1930 in the Caucasus, with descriptions of eleven new species, erection of a new monotypic genus and notes on the tribe Leucogeorgiini (Diplopoda: Julida: Julidae). European Journal of Taxonomy 713: 1-106. https://doi.org/10.5852/ejt.2020.713

Barjadze Sh., Arabuli T., Mumladze L., Maghradze E., Asanidze Z. \& Shavadze R. 2019. Cave Biodiversity of Georgia, Open Access Database. Institute of Zoology at Ilia State University. Available from https://cbg.iliauni.edu.ge/en/ [accessed: 20 Apr. 2021].

Börner C. 1904. Zur Systematik der Hexapoden. Zoologischer Anzeiger 27: 511-533.

Chen Z., Auler A., Bakalowicz M., Drew D., Griger F., Hartmann J., Jiang G., Moosdorf N., Richts A., Stevanovic Z., Veni G. \& Goldscheider N. 2017. The world karst aquifer mapping project: concept, mapping procedure and map of Europe. Hydrogeology Journal 25: 771-785.

https://doi.org/10.1007/s10040-016-1519-3

Condé B. 1956. Matériaux pour une Monographie des Diploures Campodéidés. Mémoires du Muséum National d'Histoire naturelle. Série A (Zoologie) 12: 1-202.

Condé B. 1993. Une lignée danubienne du genre Plusiocampa (Diploures Campodéidés). Revue suisse de Zoologie 100 (3): 735-745. Available from https://biodiversitylibrary.org/page/41223871 [accessed 13 Nov. 2019].

Condé B. 1996. Diploures Campodéidés de la Peştera de la Movile (Movile Cave), Dobroudja méridionales (Roumanie). Revue suisse de Zoologie 103 (1): 101-114.

Available from https://biodiversitylibrary.org/page/41267657 [accessed 13 Nov. 2019].

Ehlers J., Gibbard P.L. \& Hughes P.D. (eds) 2011. Quaternary Glaciations - Extent and Chronology. Vol. 15. Elsevier, Amsterdam. https://doi.org/10.1002/jqs.1050 
Ionescu M.A. 1955. Diplura. In: Academia Republicii Socialiste România (ed.) Fauna Republicii Populare Române, Insecta 7 (2): 1-48.

Lindgren A., Hugelius G., Kuhry P., Christensen T.R. \& Vandenberghe J. 2016. GIS-based maps and area estimates of northern hemisphere permafrost extent during the Last Glacial Maximum. Permafrost and Periglacial Processes 27: 6-16. https://doi.org/10.1002/ppp.1851

Luan Y.X., Mallatt J.M., Xie R.D., Yang Y.M. \& Yin W.Y. 2005. The phylogenetic positions of three basal-hexapod groups (Protura, Diplura, and Collembola) based on ribosomal RNA gene sequences. Molecular Biology and Evolution 22 (7): 1579-1592. https://doi.org/10.1093/molbev/msi148

Lubbock J. 1873. Monograph of the Collembola and Thysanura. Ray Society, London. https://doi.org/10.5962/bhl.title.11583

Maghradze E., Faille A., Barjadze Sh. \& Hlaváč P. 2019. A new cavernicolous species of the genus Bergrothia Reitter, 1884 (Coleoptera, Staphylinidae, Pselaphinae) from Georgia. Zootaxa 4608 (2): 371-379. https://doi.org/10.11646/zootaxa.4608.2.11

Martens J., Maghradze E. \& Barjadze Sh. 2021. Two new species of the genus Nemaspela Šilhavý from caves in Georgia (Opiliones: Nemastomatidae). Zootaxa 4951 (3): 541-558.

https://doi.org/10.11646/zootaxa.4951.3.7

Neuherz H. 1984. Torocampa hölzeli n. gen., n. spec. - eine klasobionte Campodeide (Diplura, Apterygota) aus der Hafnerhöhle in den Karawanken, Kärnten. Carinthia II 174/94: 415-427.

Olson D. \& Dinerstein E. 2002. The Global 200: priority ecoregions for global conservation. Annals of the Missouri Botanical Garden 89: 199-224. https://doi.org/10.2307/3298564

Paclt J. 1957. Diplura. In: Wytsman P. (ed.) Genera Insectorum 212: 1-123. L. Desmet-Verteneuil, Brussels.

Sendra A. \& Reboleira A.S.P.S. 2012. The world deepest subterranean community - KruberaVoronja Cave (Western Caucasus). International Journal of Speleology 41 (2): 221-230. https://doi.org/10.5038/1827-806X.41.2.9

Sendra A., Lara M.D., Ruiz Aviles F. \& Tinaut A. 2004. Une nouvelle espèce du genre Plusiocampa Silvestri, 1912 (Diplura, Campodeidae) et données pour sa reconstruction paléobiogéographique dans les Bétiques. Subterranean Biology 2: 113-122.

Sendra A., Satar A. \& Montagud S. 2006. Première contribution à la faune de Diploures Campodéidés de la Péninsule d'Anatolie, Turquie (Diplura: Campodeidae). Revue suisse de Zoologie 113 (3): 693709. Available from https://www.biodiversitylibrary.org/page/41228213 [accessed 21 Oct. 2021].

Sendra A., Teruel S., Satar A., Tusun S. \& Özbay C. 2010. New species, new records, and distribution of Campodeidae (Diplura) in Anatolia. Zootaxa 2639 (1): 40-52. https://doi.org/10.11646/zootaxa.2639.1.4

Sendra A., Arnedo M.A., Ribera C., Teruel S., Bidegaray-Batista L. \& Condé B. 2012. Revision of Cestocampa Condé (Diplura, Campodeidae), with description of a new species from caves in the eastern Iberian Peninsula. Zootaxa 3252 (1): 43-56. https://doi.org/10.11646/zootaxa.3252.1.2

Sendra A., Nicolosi G. \& Amore E. 2019. Subterranean Campodeidae fauna from Sicily Island (Diplura); its biogeographical interest with the description of a new species of Plusiocampa. Zootaxa 4679 (2): 297-317. https://doi.org/10.11646/zootaxa.4679.2.5

Sendra A., Antić D., Barranco P., Borko Š., Christian E., Delić T., Fadrique F., Faille A., Galli L., Gasparo F., Georgiev D., Giachino P.M., Kováč L., Lukić M., Marcia P., Miculinić K., Nicolosi G., Palero F., Paragamian K., Pérez T., Polak S., Prieto C.E., Turbanov I., Vailati D. \& Reboleira 
A.S.P.S. 2020a. Flourishing in subterranean ecosystems: Euro-Mediterranean Plusiocampinae and tachycampoids (Diplura, Campodeidae). European Journal of Taxonomy 591: 1-138.

https://doi.org/10.5852/ejt.2020.591

Sendra A., Palero, F., Jiménez-Valverde A. \& Reboleira A.S.P.S. 2020b. Diplura in caves: diversity, ecology, evolution and biogeography. Zoological Journal of the Linnean Society 192 (3): 675-689. https://doi.org/10.1093/zoolinnean/zlaa116

Sendra A., Jiménez-Valverde A., Selfa J. \& Reboleira ASPS. 2021a. Diversity, ecology, distribution and biogeography of Diplura. Insect Conservation and Diversity 14 (4): 415-425. https://doi.org/10.1111/icad.12480

Sendra A., Borko Š., Jiménez-Valverde A., Selfa J., Lukić M., Miculinić K., Rađa T. \& Antić D. 2021b. Cave-adapted campodeids (Hexapoda, Diplura, Campodeidae) from the Dinarides and adjacent karst regions. Revue suisse de Zoologie 128 (1): 15-52. https://doi.org/10.35929/RSZ.0033

Silvestri F. 1912. Contribuzione alla conoscenza dei Campodeidae (Thysanura) d'Europa. Bolletino del Laboratorio di Zoologia generale e agraria in Portici 6: 110-147.

Silvestri F. 1949. Descrizione di due specie nuove cavernícole di Campodeidae (Insecta Diplura) della regione del Monte Tauro. Bolletino del Laboratorio d'Entomologia agraria in Portici 9: 27-31.

Tatashidze Z., Tsikarishvili K., Jishkariani J., Jamrishvili A., Geladze G. \& Lominadze G. 2009a. Tskaltubo Cave System. Petiti Publishing House, Tbilisi [in Georgian].

Tatashidze Z.K., Tsikarishvili K.D. \& Jishkariani J.M. 2009b. The Cadastre of the Karst Caves of Georgia. Petiti Publishing House, Tbilisi [in Georgian].

Turbanov I.S., Demidov P.E., Kolesnikov V.B. \& Turbanova A.A. 2018. Preliminary results of invertebrate animal study in the Veryovkina Cave (The Western Caucasus, Abkjazia). Speleology and Spelestology. Collection of Materials of IX International Scientific Conference: 360-368. Nizhny Novgorod Pedagogical University Press, Naberezhnye Chelny.

Manuscript received: 28 May 2021

Manuscript accepted: 30 September 2021

Published on: $x x$ month 2021

Topic editor: Nesrine Akkari

Desk editor: Eva-Maria Levermann

Printed versions of all papers are also deposited in the libraries of the institutes that are members of the EJT consortium: Muséum national d'histoire naturelle, Paris, France; Meise Botanic Garden, Belgium; Royal Museum for Central Africa, Tervuren, Belgium; Royal Belgian Institute of Natural Sciences, Brussels, Belgium; Natural History Museum of Denmark, Copenhagen, Denmark; Naturalis Biodiversity Center, Leiden, the Netherlands; Museo Nacional de Ciencias Naturales-CSIC, Madrid, Spain; Real Jardín Botánico de Madrid CSIC, Spain; Zoological Research Museum Alexander Koenig, Bonn, Germany; National Museum, Prague, Czech Republic. 